\title{
POLA ASUH PERMISIF TERHADAP PENGEMBANGAN ARTIKULASI BAHASA ANAK USIA 4-5 TAHUN
}

\author{
Nur Intan Rochmawati \\ Prodi PGPAUD Universitas Ngudi Waluyo. Jalan Diponegoro Nomor 186 Gedanganak, Ungaran, \\ Kabupaten Semarang, Jawa Tengah \\ E-mail: intansamsu059@gmail.com, Telp:085325690833
}

\begin{abstract}
Abstrak
Era digital membawa berbagai macam dampak, yaitu dampak positif dan dampak negatif, terutama dalam perkembangan anak usia dini. Salah satu dari dampak yang ditimbulkan yaitu masih ada anak usia 4-5 tahun yang belum jelas dalam pengucapan bahasa, seperti contoh artikulasi bahasa tidak jelas. Hal ini dipengaruhi oleh banyak faktor antar lain faktor orang dewasa disekitar anak. Ibu sebagai orang pertama dan utama dalam memperkenalkan bahasa kepada anak hendaknya memahami tahap perkembangan bahasa anak usia dini sehingga dapat memberikan stimulasi yang tepat kepada anak dalam memperoleh bahasa. Hasil pengamatan menunjukkan bahwa pola asuh permisif lebih dominan dipilih orang tua dalam mengasuh anak usia dini.Anak diberi mainan gadget atau telepon genggam tanpa pendampingan. Sehingga menyebabkan anak sibuk dengan mainannya sendiri yang akhirnya tidak membiasakan/ melatih anak untuk mengucapkan kata atau berbicara dengan orang dewasa disekeliling bahkan teman sebayanya.Dampakdari pola asuh permisif pada dari profil anak antara lain anak usia 4-5 tahun mengalami kesulitan dalam pengucapan. Ada banyak faktor yang mempengaruhi anak usia 4-5 tahun yang mengalami kesulitan dalam mengucapkan artikulasi, contoh susu dalam pengucapan menjadi cucu, coklat dalam pemgucapan menjadi totat, dan seterusnya. Perlu perhatian dan penanganan yang cepat supaya perkembangan bahasa anak sesuai dengan tahapan perkembangan usianya.
\end{abstract}

Kata kunci: Pola Asuh Permisif, Artikulasi Bahasa, Anak Usia Dini.

\section{PERMISIVE FOREIGN PATTERNS ON DEVELOPMENT OF CHILDREN'S LANGUAGE ARTICULATION OF 4-5 YEARS}

\begin{abstract}
The digital age brings a variety of impacts, namely positive and negative impacts, especially in early childhood development. One of the impacts is that there are still children aged 4-5 years who are not yet clear in the pronunciation of language, such as examples of language articulation is not clear. This is influenced by many factors, among other factors adults around children. Mothers as first and foremost people in introducing language to children should understand the stage of language development in early childhood so that it can provide appropriate stimulation to children in acquiring language. The results of observations show that permissive parenting is more dominantly chosen by parents in caring for early childhood. Children are given gadget toys or cellphones without assistance. So that causes children to be busy with their own toys which ultimately do not accustom / train children to say words or talk to adults around even their peers. The impact of permissive parenting on the profile of children, among others, children aged 4-5 years has difficulty in pronunciation.There are many factors that affect children aged 4-5 years who have difficulty in pronouncing articulation, examples of milk in pronunciation into grandchildren, chocolates in speech become totat, and so on. Need attention and quick handling so that children's language development is in accordance with the developmental stages of his age.
\end{abstract}

Keywords: Permissive Upbringing, Language Articulation, Early Childhood 


\section{PENDAHULUAN}

Manusia sebagai mahluk sosial tidak mampu untuk hidup sendiri di lingkungannya, akan tetapi membutuhkan manusia lain untuk berinteraksi dan bersosialisasi dengan manusia atau dengan mahluk ciptaan Tuhan lainnya. Salah satu cara untuk memperlancar manusia dalam bersosialisasi adalah bahasa. Bahasa merupakan sarana bagi sesorang untuk melakukan komunikasi dengan orang lain. Melalui bahasa komunikasi terjalin dengan baik, meskipun menggunanakan bahasa isyarat. Keterbatasan bahasa dapat mempengaruhi persepsi seseorang dalam menterjemahkan maksud dan keinginan seseorang dalam menyampaikan sesuatu, akan tetapi hal ini dapat teratasi jika dalam berkomunikasi dilandasi dengan kasih sayang dan hati yang tulus serta pikiran jernih sehingga tidak memunculkan pikiran negatif atau suúdzon. Dasar utama dalam berinteraksi dan bersosialisasi seseorang adalah hati yang bersih artinya menjauhkan prasangka terhadap orang lain dan lingkungannya dituangkan dalam ungkapan bahasa yang indah.

Anak usia 4-5 tahun dalam memperoleh bahasa berasal dari orang-orang dewasa disekitarnya. Ibu sebagai orang pertama dan utama dalam memperkenalkan bahasa kepada anak hendaknya memahami tahap perkembangan bahasa anak usia dini sehingga dapat memberikan stimulasi yang tepat kepada anak dalam memperoleh bahasa. Usia 4-5 tahun merupakan usia sekolah di mana anak belajar bersosialisasi di jenjang sekolah bersama teman sebaya dan orang dewasa dalam hal ini guru dan orang tua.

Hari pertama di sekolah merupakan awal perkenalan anak-anak untuk berkenalan dengan teman-teman barunya. Tangisan anak adalah proses adaptasi di sekolah. Anak yang terbiasa bersosialisasi akan mudah untuk beradaptasi dilingkungan yang baru. Berbeda dengan anak yang terbiasa dikurung di rumah bersama pengasuhnya akan kesulitan untuk menyesuaikan diri dengan lingkungan yang baru yaitu sekolah.

Saat masa orientasi di sekolah guru memberikan rangsangan berupa lagu-lagu dan permainan serta berbagai macam tepuk. Anak akan menirukan apa yang ibu guru ajarkan. Muncul kata-kata yng kurang jelas dari bibir anak-anak, seperti: bu gulu $=$ bu guru, atal $=$ nakal. Dili sendili $=$ diri sendiri $($ tema awal). Ungkapan yang keluar dari bibir anak usia 4-5 tahun ini dengan jelas terdengar oleh guru sebagai fasilitator di sekolah. Guru yang tanggap segera memberi penguatan dengan memperjelas kata demi kata dengan gerak bibir yang sesuai dengan bunyi dari kata tersebut. Hal ini dapat membantu anak untuk menyadari bahwa kata yang diucapkannya tidak tepat. Seiring berjalannya waktu ungkapan yang keluar dari bibir anak usia dini akan berubah sesuai dengan apa yang diajarkan oleh guru, dengan catatan tidak terdapat hambatan/gangguan dari faktor lain.

Orang tua dan keluarga adalah media bagi anak usia dini untuk mengembangkan semua aspek yang dimiliki oleh anak seperti kognitif, bahasa, nilai agama dan moral, sosial emosional serta fisik motoriknya. Upaya menstimulasi perkembangan tersebut perlu dilakukan secara kompak dan terus menerus, bertahap serta konsisten didasari dengan kasih sayang dipatri dengan keteladanan. Jika hal ini dilakukan maka perkembangan anak akan melejit dan anak tumbuh menjadi anak yang berkembang sesuai tahapannya.

Pola asuh orang tua sangat mempengaruhi perkembangan anak. Pola asuh yang diterapkan di dalam keluarga tergantung dari bagaimana orang-orang dewasa di sekitar anak memberikannya dalam pembiasaan sehari-hari. Setiap keluarga mempunya kebebasan untuk membentuk pola masing-masing hal ini dipengaruhi oleh ilmu warisan dari orang tuanya dahulu, latar belakang pendidikan, kondisi lingkungan, budaya, masalah ekonomi keluarga.

Berbagai faktor yang menyebabkan pola asuh keluarga berbeda-beda. Kenyataan yang terjadi di lapangan terlihat bahwa banyak terdapat anak usia dini yang mengalami perkembangan bermacam-macam. Fenomena anak yang sering marah, mau menang sendiri tidak bisa ditegur dikarenakan pola asuh yang diterapkan di dalam keluarganya. Seorang ibu yang sibuk bekerja dengan alasan faktor ekonomi menjadikan kewajiban utamanya untuk mendidik anak menjadi terbengkelai. Sehingga menyebabkan anak diasuh dengan neneknya atau dititipkan tetangganya atau orang yang dianggap bias menjaga anaknya. Berdasarkan latar belakang diatas diangkatlah sebuah judul penelitian yaitu Pola Asuh Permisif Terhadap Pengembangan Artikulasi Bahasa Anak Usia 4-5 tahun. 


\section{ANAK USIA DINI}

Anak usia dini adalah anak yang berada pada rentang 0-6 tahun ( Undang-undang Sisdiknas tahun 2003). Pendapat lain mengatakan anak usia dini adalah anak yang berada pada usia 0-8 tahun. Menurut Beichler dan Snowman dalam Dwi Yulianti (2010:7) anak usia dini adalah anak yang berusi 3-6 tahun. Sebagaimana dikemukakan oleh Santrock (1993) meliputi urutan sebagai berikut: Periode pra kelahiran (prenatal period), periode bayi (infacy period), periode awal anak-anak (early childhood period), periode pertengahan dan akhir anak anak (middle and late childhood period), periode remaja (adolescence period), periode awal dewasa (early adulthood period), periode pertengahan dewasa (middle adulthood period), dan periode akhir dewasa (late adulthood period). Bahasa dan komunikasi yang khusus yang sesuai dengan ahapan yang sedang dilalui oleh anak tertentu.

Aspek-aspek perkembangan anak usia dini yaitu aspek nilai agama dan moral, aspek Bahasa, aspek kognitif, aspek, fisik motorik, aspek sosial emosinal anak yang kesemuanya itu wajib dikembangkan sebagai bekal kehidupannya kelak. Perlu diketahui pula bahwa aspek-aspek tersebut saling terkait dan terintegrasi didalam diri anak usia dini. Sebagaimana terdapat di dalam Permendikbud Nomor 137 tahun 2014 tentang Standar PAUD dijelaskan bahwa standar tingkat pencapaian perkembangan anak harus dipahami dan diaplikasikan dalam memberikan stimulasi kepada anak usia dini. STPPA dikelompokkan sesuai dengan umur yaitu kelompok usia lahir12 bulan, kelompok usia 12-24 bulan, kelompok 2-4 tahun, dan kelompok 4-6 tahun. Sedangkan tahapan perkembangan yang dilalui meliputi lingkup perkembangan nilai agama dan moral, lingkup perkembangan fisik motorik meliputi motorik kasar, motorik halus, kesehatan dan perilaku keselamatan selanjutnya lingkup perkembangan kognitif meliputi mengenali lingkungan, meunjukkan reaksi atas rangsangan, lingkup perkembangan Bahasa, lingkup perkembangan sosial emosional dan terakhir lingkup perkembangan seni meliputi mampu membedakan antara bunyi dan suara, tertari dengan suara atau musik, tertarik dengan berbagai macam karya seni.

\section{POLA ASUH DAN JENISNYA}

Pola asuh adalah pola perilaku yang diterapkan pada anak dan bersifat relatif konsistensi dari waktu ke waktu. Dalam mengasuh anak orang tua cenderung menggunakan pola asuh tertentu,,terdapat 3 macam pola asuh orang tua sebagaimana terdapat dalam Lilis (2017) yaitu:

a. Demokratis

Pola asuh demokratis adalah pola asuh yang memprioritaskan kepentingan anak, akan tetapi tidak ragu dalam mengendalikan mereka. Orang tua dengan perilaku ini bersikap rasional, selalu mendasari tindakannya pada rasio atau pemikiran-pemikiran. Orang tua tipe ini juga bersikap realistis terhadap kemampuan anak, tidak berharap yang berlebihan yang melampaui kemampuan anak. orang tua tipe ini juga memberikan kebebasan kepada anak untuk memilih dan melakukan suatu tindakan dan pendekatannya kepada anak bersifat hangat. (Ira Petranto, 2005). Misalnya ketika orang tua menetapkan untuk menutup pintu kamar mandi ketika sedang mandi dengan diberi penjelasan, mengetuk pintu ketika masuk kamar orang tua, memberikan penjelasan perbedaan laki-laki dan perempuan, berdiskusi tentang hal yang tidak boleh dilakukan anak misalnya tidak boleh keluar dari kamar mandi dengan telanjang, sehingga orang tua yang demokratis akan berkompromi dengan anak. (Debri, 2008)..

b. Otoriter

Pola asuh ini sebaliknya cenderung menetapkan standar yang mutlak harus dituruti, biasanya dibarengi dengan ancaman-ancaman mislalnya, kalau tidak mau makan, maka tidak akan diajak bicara. Orang tua tipe ini cenderung memaksa, memerintah dan menghukum. Apabila anak tidak mau melakukan apa yang dikatakan oleh orang tua, maka orang tua tipe ini tidak segan menghukum anak. Orang tua tipe ini juga tidak mengenal kompromi dan dalam berkomunikasi biasanya bersifat satu arah. (Ira Petranto, 2005). Misalnya anaknya harus menutup pintu kamar mandi ketika mandi tanpa penjelasan, anak laki-laki tidak boleh bermain dengan anak perempuan, melarang anak bertanya kenapa dia lahir, anak dilarang bertanya tentang lawan jenisnya. Dalam hal ini tidak mengenal kompromi. Anak suka atau tidak suka, mau atau tidak mau harus memenuhi target yang ditetapkan orang tua. Anak adalah obyek yang harus dibentuk orang tua yang 
merasa lebih tahu mana yang terbaik untuk anak-anaknya. (Debri, 2008).

c. Permisif

Pola asuh ini memberikan kesempatan pada anaknya untuk melakukan sesuatu tanpa pengawasan yang cukup dari orang tua. Mereka cenderung tidak menegur/memperingatkan anak apabila anak sedang dalam bahaya dan sangat sedikit bimbingan yang diberikan oleh mereka, sehingga seringkali disukai oleh anak. (Ira Petranto, 2005). Misalnya anak yang masuk kamar orang tua tanpa mengetuk pintu dibiarkan, telanjang dari kamar mandi dibiarkan begitu saja tanpa ditegur, membiarkan anak melihat gambar yang tidak layak untuk anak kecil, dengan pertimbangan anak masih kecil. Sebenarnya, orang tua yang menerapkan pola asuh seperti ini hanya tidak ingin konflik dengan anaknya (Debri, 2008).

Dalam sebuah penelitian menyatakan bahwa Pola asuh demokratis lebih banyak didapatkan anak dengan konsep diri positif $73,3 \%$, sedangkan pola asuh otoriter dan permisif didapatkan lebih banyak anak dengan konsep diri negatif yaitu $18,9 \%$ dan $28,4 \%$. Saran diberikan kepada para orang tua agar menerapkan pola asuh demokratis dimana anak 10-12 tahun dengan konsep diri positif terbanyak didapatkan dari pola asuh tersebut

\section{TAHAPAN PERKEMBANGAN BAHASA PADA ANAK}

Saat bayi baru lahir sampai usia satu tahun, lazim disebut dengan istilah infant artinya tidak mampu berbicara. Istilah ini memang tepat kalau dikaitkan dengan kemampuan seseorang dalam berbicara. Perkembangan bahasa bayi dapat dibagi menjadi dua yaitu ; 1)tahap perkembangan artikulasi, dan 2) tahap perkembangan kata dan kalimat (Poerwo, 1989).

\section{TAHAP PERKEMBANGAN ARTIKULASI}

Pada tahap perkembangan artikulasi pada anak usia dini dilalui sebagai berikut:

a. Bunyi Resonansi

Penghasilan bunyi, yang terjadi dalam rongga mulut, tidak terlepas dari kegiatan dan perkembangan montorik bayi pada bagian rongga mulut. Baunyi yang paling umum yang dapat dibuat bayi adalah bunyi tangis karena merasa tidak enak atau merasa lapar dan bunyibunyi sebagai batuk, bersin, dan sedawa. Disamping itu, ada pula bunyi bukan tangis yang disebut bunyi "kuasi resonansi, bunyi ini belum ada konsonannya dan vokalnya belum sepenuhnya mengandung resonansi.

b. Bunyi Berdekut

Mendekati usia dua bulan bayi telah mengembangan kendali otot mulut untuk memulai dan mengentikan gerakan secara mantap. Pada tahap ini suara tawa dan suara berdekut (cooking) telah terdengar. Bunyi berdekut ini agak mirip dengan bunyi [ooo] pada burung merpati. Bunyi yang dihasilkan adalah bunyi konsonan belakang dan tengah dengan vocal belakang, tetapi dengan resonansi penuh. Bunyi konsonannya mirip dengan bunyi [s] dan bunyi hampat velar yang mirip dengan bunyi $[\mathrm{k}]$ dan $[\mathrm{g}]$.

c. Bunyi Berleter

Berleter adalah mengelurkan bunyi yang terus menerus tanpa tujuan. Berleter ini biasanya dilakukan oleh bayi yang berusia antara empat sampai enam bulan.

\section{d. Bunyi Berleter Ulang}

Tahap ini dilalui si anak berusia antara enam sampai sepuluh bulan. Konsonan yang mula-mula dapat diucapkan adalah bunyi labial [p] dan [b], bunyi letup alveolarm [t] dan [d], bunyi nasal [j]. Yang paling umum terdengar adalah bunyi suku kata yang merupakan rangkaian konsonan dan vocal seperti "ba-baba" atau "ma-ma-ma".

e. Bunyi Vokabel: suku kata ke kata

Vakabel adalah bunyi yang hamper menyerupai kata, tetapi tidak mempunyai arti dan bukan merupkan tiruan orang dewasa. Vokabel ini dapat dihasilkan oleh sang anak antara usia 11 sampai 14 bulan (Anonim, 2019a)

\section{TAHAP PERKEMBANGAN KATA DAN KALIMAT}

Kemampuan bervakabel dilanjutkan dengankemampuan mengucapkan kata, lalu mengucapkankalimat sederhana, dan kalimat yang lebih sempurna.

\section{a. Kata Pertama}

Kemampuan mengucapkab kata pertama sangat ditentukan oleh penguasaan artikulasi, dan oleh kemampuabn mengaitkan kata dengan benda yang menjadi rujukkan (de Vilers, 1097 dalam Purwo, 1989). Pada tahap ini anak cenderung menyederhanakan pengecapannya yang dilakukan secara sistematis.

\section{b. Kalimat Satu Kata}

Kata pertama yang berhasil diucapkan anak akan disusul oleh kata kedua, ketiga, keempay dan seterusnya. Kalimat satu kata yang lazim disebut ucapan holofrasis. 
c. Kalimat Dua kata

Yang dimaksud dengan kalimat dua kata adalah kalimat yang hanya terdiri dari dua buah kata, sebagai kelanjutan dari kalimat satu kata.d. d. Kalimat Lebih lanjut

Pernguasaan kalimat dua kata mencapai tahap tertentu, maka berkembanglah penyusunan kalimat yang terdiri dari tiga buah kata.

\section{GANGGUAN ARTIKULASI PADA ANAK}

Anak-anak yang bicaranya tak jelas atau sulit ditangkap dalam istilah psikologi/psikiatri disebut mengalami gangguan artikulasi atau fonologis. Namun gangguan ini wajar terjadi karena tergolong gangguan perkembangan. Dengan bertambah usia, diharapkan gangguan ini bisa diatasi (Anonim, 2019b).

Kendati begitu, gangguan ini ada yang ringan dan berat. Yang ringan, saat usia 3 tahun si kecil belum bisa menyebut bunyi L, R, atau $\mathrm{S}$. Hingga, kata mobil disebut mobing atau lari dibilang lali. "Biasanya gangguan ini akan hilang dengan bertambah usia anak atau bila kita melatihnya dengan membiasakan menggunakan bahasa yang baik dan benar," jelas Dra. Mayke S. Tedjasaputra. Hanya saja, untuk anak yang tergolong "pemberontak" atau negativistiknya kuat, umumnya enggan dikoreksi. Sebaiknya kita tak memaksa meski tetap memberitahu yang benar dengan mengulang kata yang dia ucapkan. Misal, "Ma, yuk, kita lali-lali!", segera timpali, "Oh, maksud Adik, lari-lari."Yang tergolong berat, anak menghilangkan huruf tertentu atau mengganti huruf dan suku kata. Misal, toko jadi toto atau stasiun jadi tatun. "Pengucapan semacam ini, kan, jadi sulit ditangkap orang lain," ujar pengajar di Fakultas Psikologi UI dan konsultan psikologi di LPT UI ini.

\section{PENYEBAB GANGGUAN ARTIKULASI PADA ANAK}

Gangguan fonologis bisa dikarenakan faktor usia yang mengakibatkan alat bicara atau otot-otot yang digunakan untuk berbicara (speech motor) belum lengkap atau belum berkembang sempurna; dari susunan gigi geligi, bentuk rahang, sampai lidah yang mungkin masih kaku. Beberapa kasus gangguan ini malah berkaitan dengan keterbelakangan mental. Anak yang kecerdasannya tak begitu baik, perkembangan bicaranya umumnya juga akan terganggu. Bila gangguan neurologis yang jadi penyebab, berarti ada fungsi susunan saraf yang mengalami gangguan. Sebab lain, gangguan pendengaran. Bila anak tak bisa mendengar dengan jelas, otomatis perkembangan bicaranya terganggu. Tak kalah penting, faktor lingkungan, terutama bila anak tidak/kurang dilatih berbicara secara benar (Anonim, 2019c)..

\section{POLA ASUH PERMISIF TERHADAP PENGEMBANGAN BAHASA ANAK USIA 4-5 TAHUN}

Pola asuh permisif membiarkan anak untuk melakukan tindakan semaunya tanpa ada teguran. Lebih terkesan adanya pembiaran, hal ini sangatlah bertolak belakang dengan kebutuhan anak usia dini seperti perhatian dan pendampingan serta pembimbingan (Anonim, 2019d).

Pengembangan artikulasi bahasa anak usia dini wajib dikawal oleh orang tua dan lingkungannya. Pengembangan artikulasi bahasa anak usia 4-5 sangat memerlukan bimbingan dan pendampingan setiap saat oleh orang-orang disekitar anak.

Jika masa yang terpenting untuk didampingi dalam setiap langkah akan tetapi dengan pola asuh permisif menjadikan anak dibiarkan meskipun berbuat salah, tanpa ada pembenaran. Akibatnya perkembangan bahasa terutama artikulasi bahasa dapat menjadi terhambat. Hal ini jika tidak segera disadari orang tua maka anak kurang maksimal pengembangan bahasanya. Orang tua perlu mengikuti masa-masa anak saat melewati tahap -tahap perkembangannya. Segera lakukan pendampingan anak usia dini dalam memperoleh pengembangan bahasanya.

\section{PENUTUP}

Perkembangan anak usia dini pada pengembangan artikulasi anak usia 4-5 tahun memerlukan perhatian dan pendampingan setiap harinya. Pola asuh permisif memberikan pengasuhan dengan pembiaran memberikan pengasuhan dengan kebebasan tanpa ada aturan yang tertib dan konsistensi Terkait dengan pengembangan artikulasi bahasa anak usia 4-5 tahun memerlukan pendampingan dan pembimbingan. Melalui stimulasi dan pendampingan serta pembiasaan dalam pengucapan kata-kata yang benar dapat meningkatkan pengembangan artikulasi Bahasa anak usia 4-5 tahun. Selain itu latihan menirukan ucapan yang benar dari orang dewasa di sekitar anak. 


\section{DAFTAR PUSTAKA}

Anonim. 2019a. Psikologi Perkembangan Bahasa Anak. [Online]. Tersedia: http://sinaubsi.blogspot.com/p/psikol ogi-perkembangan-bahasa-anak.html [ 8 Januari 2019] 2019b. Gangguna Artikulasi Pada Anak. [Online]. Tersedia: www.balitabunda.com/gangguanartikulasi-pada-anak [ 8 Januari 2019].

2019c. Gangguan Artikulasi Pada Anak. http://pembelajarananak.blogspot.com/2009/12/ganggua n-artikulasi-pada-anak.html $[8$ Januari 2019].

2019d. Pengertian Pola Asuh Menurut Para Ahli, Definisi, Contoh, Macam. [Online]. Tersedia: http://www.sarjanaku.com/2012/12/p engertian-pola-asuh-menurut-paraahli.html [8 Januari 2019]

Debri. 2008. Sosio-Emosional Anak. [Online]. Tersedia: https://jurnalilmiahsosioemosionalanak.blogspot.com/ [8 Januari 2019]

Dwi Yulaini. 2019. Anak Usia Dini. [Online]. Tersedia: https://eprints.uny.ac.id/7778/3/bab $\% 202 \% 20-\% 2009111247009$.pdf [12 Januari 2018]

Habibi, M. A. Muazar, 2018, Analisis Kebutuhan Anak Usia Dini, Yogyakarta: Deepublish

Ira Petranto. 2005. Pola Asuh Anak. [Online]. Tersedia: http://www.polaasuhanak.com. [ 20 Januari 2019].

Jannah, H. 2012. Bentuk Pola Asuh Orang Tua Dalam Menanamkan Perilaku Moral Pada Anak Usia Di Kecamatan Ampek Angkek. Pesona Paud, 1(1) :257-258.
Lilis, Madyawati. 2017. Strategi Pengembangan Bahasa Pada Anak. Kencana: Jakarta

Ni Made Taganing. 2018. Hubungan Pola AsuhOtoriter dengan Perilaku Agresif Pada Remaja.[Online]. Tersedia: publication.gunadarma.ac.id/bitstrea m/123456789/1882/1/Artikel... . PDF file [20 Desember 2018.

Poerwo. 1989. Tahap Perkembangan Bahasa Pada Anak. [Online]. Tersedia: http://tugaskuliah15.blogspot.com/20 15/10/tahap-perkembangan-bahasapada-anak.html. [10 Januari 2019].

Santrock, 2007, Perkembangan Anak, Jakarta: Erlangga 